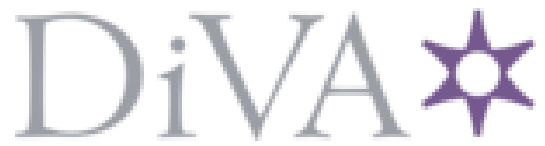

http://www.diva-portal.org

This is the published version of a paper published in .

Citation for the original published paper (version of record):

Chen, H., Sun, D., Tian, Y., Fan, H., Liu, Y. et al. (2020)

Surface-Directed Structural Transition of Amyloidogenic Aggregates and the Resulting Neurotoxicity

ACS OMEGA, 5(6): 2856-2864

https://doi.org/10.1021/acsomega.9bo3671

Access to the published version may require subscription.

N.B. When citing this work, cite the original published paper.

Permanent link to this version:

http://urn.kb.se/resolve?urn=urn:nbn:se:umu:diva-169868 


\title{
Surface-Directed Structural Transition of Amyloidogenic Aggregates and the Resulting Neurotoxicity
}

\author{
Hao Chen," Dan Sun, ${ }^{\#}$ Yin Tian, Haiming Fan, Yonggang Liu, ${ }^{*}$ Ludmilla A. Morozova-Roche,*
} and Ce Zhang*

Cite This: ACS Omega 2020, 5, 2856-2864

Read Online

\section{ACCESS | Lill Metrics \& More | 回 Article Recommendations ｜（） Supporting Information}

ABSTRACT: The transition of amyloidogenic species into ordered structures (i.e., prefibrillar oligomers, protofibrils, mature fibrils, and amyloidogenic aggregates) is closely associated with many neurodegenerative disease pathologies. It is increasingly appreciated that the liquid-solid interface contributes to peptide aggregation under physiological conditions. However, much remains to be explored on the molecular mechanism of surface-directed amyloid formation. We herein demonstrate that physical environmental conditions (i.e., negatively charged

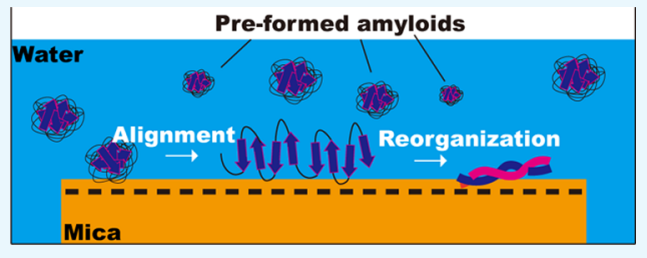
surface) affect amyloid formation. Nontoxic amyloid aggregates quickly develop into intertwisting fibrils on a negatively charged mica surface. These fibrillar structures show significant cytotoxicity on both neuroblastoma cell-lines (SH-SY5Y) and primary neural stem cells. Our results suggest an alternative amyloid development pathway, following which A $\beta$ peptides form large amyloidogenic aggregates upon stimulation, and later transit into neurotoxic fibrillar structures while being trapped and aligned by a negatively charged surface. Conceivably, the interplay between chemical and physical environmental conditions plays important roles in the development of neurodegenerative diseases.

\section{INTRODUCTION}

Among many, the most characteristic pathological feature of neurodegenerative diseases is the formation of amyloidogenic species originating from protein misfolding. ${ }^{1-22}$ Despite the biological and clinical significance, the underlying mechanisms of amyloid formation in vivo and its correlation with pathophysiological symptoms remain unclear. Numerous factors including elevated temperature, shearing force, low $\mathrm{pH}$, salt concentration, liquid-substrate interfaces, and hydrophilic or hydrophobic surfaces were reported to contribute to amyloid formation. ${ }^{23-32}$ Moreover, the origin of cytotoxicity during amyloid development in vivo is still on debate. The belief in the cytotoxicity of both fibril (protofibrils or mature fibrils) and intermediate oligomeric amyloidogenic species is challenged. ${ }^{33-44}$

Increasing evidence indicates that complex physical and chemical environmental conditions (i.e., fluctuating levels of secretases, ligands, and mechanical cues) affect cell fate. It is conceivable that pathophysiological symptoms may be caused by interplay among varieties of contributors. Our earlier study reveal that both the secretion of the proinflammatory factor S100A9 and micelles originating from fatty acids trigger the formation of large amyloid aggregates, which may act as a sink for toxic species to mediate neuron damage. ${ }^{45,46}$ The presence of solid-liquid interface substrates provides templates for the misfolding and ordering of amyloidogenic proteins into fibrils, and eventually plaques. ${ }^{47,48}$ However, how physical environments facilitate the transition from large amyloid aggregates to ordered structures and affect the neuron system is not yet understood. ${ }^{47,49}$

Hen egg white lysozyme (HEWL) is highly homologous in sequence and structure to human lysozyme; therefore, it is commonly used as a model protein for the investigation of amyloid aggregation. ${ }^{50,51}$ Accumulated $\mathrm{A} \beta$ peptides are the main component of senile plaques and are derived from the proteolytic cleavage of a larger glycoprotein named amyloid precursor protein. ${ }^{52,53}$ In this study, HEWL and $\mathrm{A} \beta(1-40)$ amyloid aggregates were formed by agitation (continuous shaking), and later deposited on a freshly cleaved mica surface for further development. The effect of surface-directed amyloids on neural stem cells (NSCs) and SH-SY5Y behavior and viability was observed in real time using fluorescence microscopy (FM). It is demonstrated that intertwisting fibrillar structures are produced from preformed amyloidogenic aggregates but not from freshly dissolved monomers. The sodeveloped amyloid fibrils induce significant toxicity in both NSCs and SH-SY5Y cells. Our results suggest that the negatively charged surface interacts with the originally helpful amyloid aggregates (mediating OA and S100A9 toxicity), and triggers the formation of neurotoxic amyloid structures.

Received: October 31, 2019

Accepted: January 27, 2020

Published: February 6, 2020 

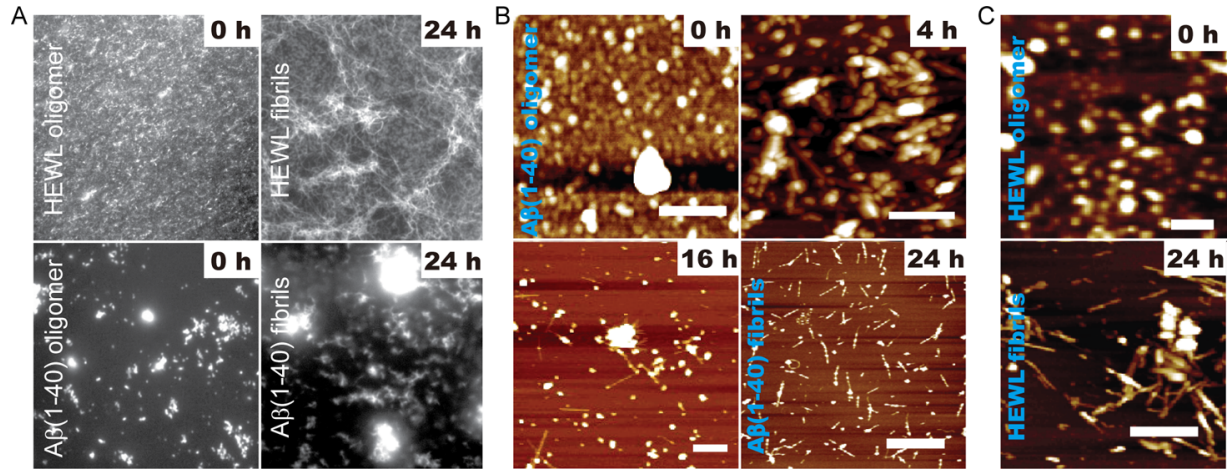

Figure 1. Fluorescence microscopy (FM) and atomic force microscopy (AFM) images of amyloid $\beta(1-40)$ and HEWL fibril formation directed by the mica surface. (A) FM and (B,C) AFM images of HEWL and A $\beta(1-40)$ oligomers and fibrils reveal that the negatively charged mica surface facilitates morphological transition of preformed oligomers to fibrillar structures. To form amyloidogenic oligomers, $10 \mathrm{mg} / \mathrm{mL} \mathrm{HEWL}$ and 0.1 $\mathrm{mg} / \mathrm{mL} \mathrm{A} \beta(1-40)$ were subjected to continuous shaking at $800 \mathrm{rpm}\left(57{ }^{\circ} \mathrm{C}\right.$ for $\mathrm{HEWL}$ and $37{ }^{\circ} \mathrm{C}$ for $\mathrm{A} \beta(1-40)$ for $24 \mathrm{~h}$. The preformed oligomers are then deposited on the mica surface. Amyloid fibrils dominate the surface after incubation of entire mica pieces in deionized (DI) water for $24 \mathrm{~h}$. For fluorescence imaging, all samples are stained by flushing with $100 \mathrm{mM}$ ThT solution, followed by imaging using a $60 \times$ oil immersion objective lens. As ThT molecules bind specifically to the beta-sheet structures, the fluorescent images show the development of amyloidogenic structures. Scale bars denote $500 \mathrm{~nm}$ in all AFM images.

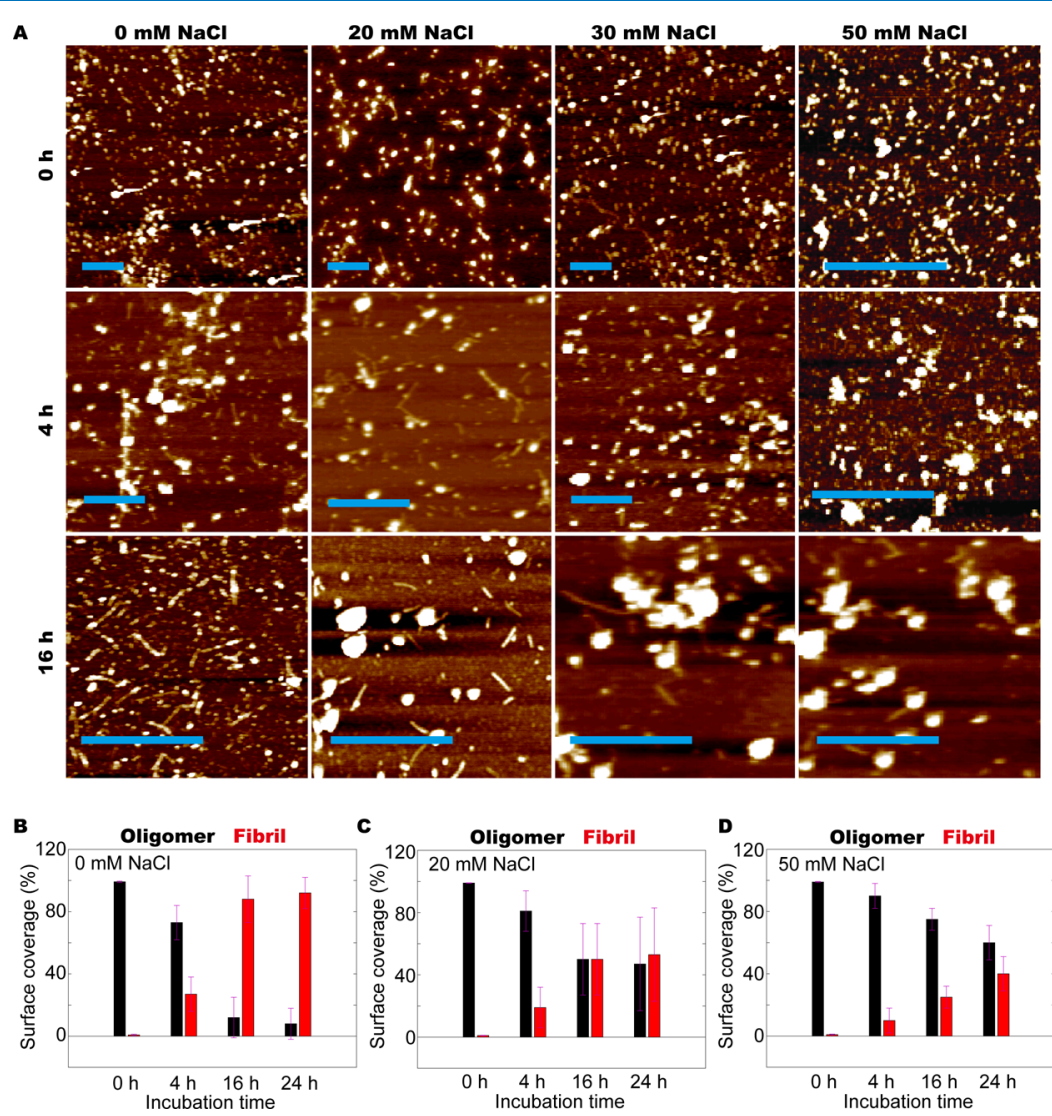

Figure 2. (A) AFM images show $A \beta(1-40)$ structures during transition from pre-formed amyloid aggregates to fibrils on the mica surface with different ionic strengths. Following the deposition on the mica surface, amyloidogenic species are incubated in DI water for $0 \mathrm{~h}$ (top panel), $4 \mathrm{~h}$ (middle) and $16 \mathrm{~h}$ (bottom) before imaging. The scale bars denote $1000 \mathrm{~nm}$ in all figures. (B-D) Ratio between $\mathrm{A} \beta$ oligomers and fibrillar structures is estimated by measuring the surface coverage percentage. To perturb electrostatic interactions between the $A \beta$ peptide and mica surface, (B) 0 , (C) 20 , and (D) $50 \mathrm{mM} \mathrm{NaCl}$ are added to the development solution. Our results demonstrate that with the emergence of fibrillar structures, there is a significant decrease in the quantities of oligomers, suggesting structural transition. The transition is affected by environmental ionic strength.

\section{RESULTS AND DISCUSSION}

Surface-Directed HEWL and $A \beta(1-40)$ Fibril Formation. Freshly dissolved solutions of $10 \mathrm{mg} / \mathrm{mL}$ HEWL and 0.1 $\mathrm{mg} / \mathrm{mL} \mathrm{A} \beta(1-40)$ were positioned under agitation at $800 \mathrm{rpm}$ and elevated temperature as described in the Methods section for $24 \mathrm{~h}$. Thioflavin-T (ThT) binding assay of HEWL shows a slow increase during the first $24 \mathrm{~h}$, which is followed by a steep rise of ThT fluorescence intensity during our observation time until ca. $125 \mathrm{~h}$ (Figure S1). The absence of the lag phase in the ThT intensity curve indicates the rapid formation of HEWL 


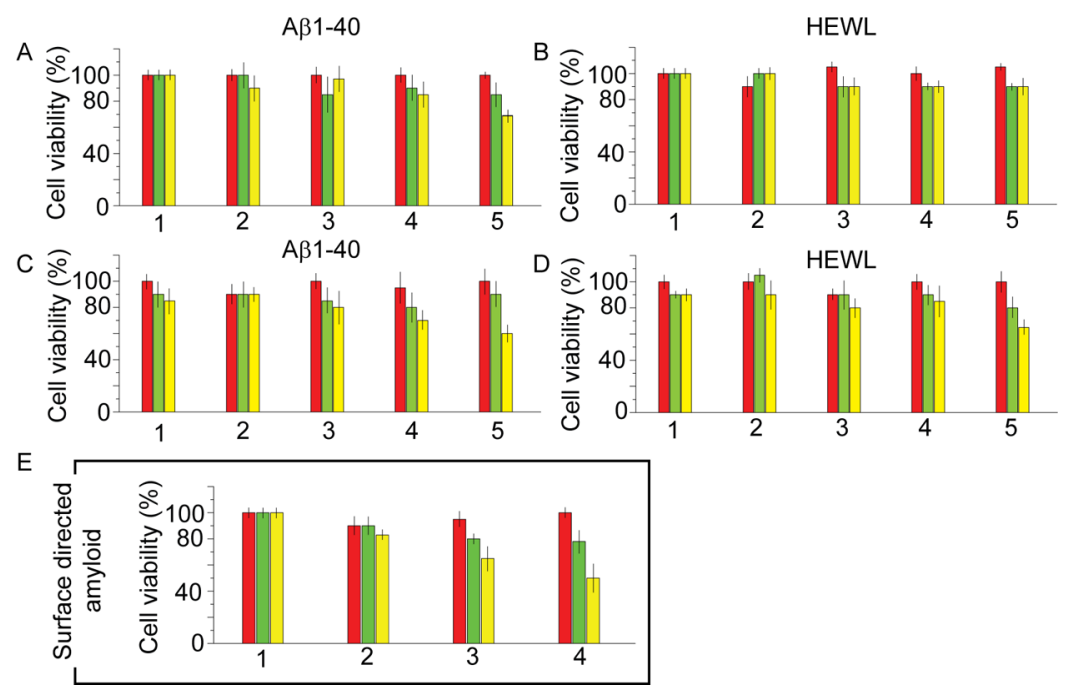

Figure 3. Measurements of SH-SYSY cell line viability by WST-1 assay in the presence of A $\beta(1-40)$ and HEWL samples. The red, green and yellow colors represent 1 day, 2 days and 3 days coincubation with A $\beta(1-40)$ and HEWL, respectively. In figure (A) and (B), the columns represent: (1) control experiments: the cells were incubated in DMEM cell culture medium alone and the cell viability was equal to $100 \%$; $(2)$ $\mathrm{A} \beta(1-40)$ and HEWL dissolving buffer; (3) freshly dissolved $\mathrm{A} \beta(1-40)$ peptide and HEWL, respectively; (4) $\mathrm{A} \beta(1-40)$ and HEWL amyloid aggregates obtained upon agitation (continuous shaking at $800 \mathrm{rpm}$ at $57^{\circ} \mathrm{C}$ for HEWL and $37{ }^{\circ} \mathrm{C}$ for $\mathrm{A} \beta(1-40)$ ) for $24 \mathrm{~h}$; (5) A $\beta(1-40)$ and HEWL amyloid aggregates obtained upon agitation for $3 \mathrm{~d}$. In figure (C) and (D), various concentrations of preformed $\mathrm{A} \beta(1-40)$ and $\mathrm{HEWL}$ amyloid aggregates are obtained using centrifugal filtering tube, and incubated with SH-SY5Y cells to assess viability, (1) $10 \mathrm{mg} / \mathrm{ml} \mathrm{HEWL} \mathrm{and} 0.1$ $\mathrm{mg} / \mathrm{ml} \mathrm{A} \beta(1-40)$, respectively; (2) $2 \times 10 \mathrm{mg} / \mathrm{ml} \mathrm{HEWL}$, and $2 \times 0.1 \mathrm{mg} / \mathrm{ml} \mathrm{A} \beta(1-40) ;(3) 3 \times 10 \mathrm{mg} / \mathrm{ml} \mathrm{HEWL,} \mathrm{and} 3 \times 0.1 \mathrm{mg} / \mathrm{ml}$ $\mathrm{A} \beta(1-40)$; (4) $4 \times 10 \mathrm{mg} / \mathrm{ml} \mathrm{HEWL}$, and $4 \times 0.1 \mathrm{mg} / \mathrm{ml} \mathrm{A} \beta(1-40)$; (5) $5 \times 10 \mathrm{mg} / \mathrm{ml} \mathrm{HEWL}$ and $5 \times 0.1 \mathrm{mg} / \mathrm{ml} \mathrm{A} \beta(1-40)$. In figure (E): (1) control experiments: the cells were incubated in DMEM cell culture medium alone and the cell viability was equal to $100 \%$. (2) control experiments: the cells were incubated in DMEM cell culture medium on bare mica surface. (3) on mica surface-directed HEWL fibrils. (4) on surface-directed $\mathrm{A} \beta(1-40)$ fibrils.

amyloid species under agitation. Using both fluorescence imaging (FM) and atomic force microscopy (AFM), the HEWL amyloids formed at the initial stage were characterized by a round-shaped morphology (Figure 1A), and heights ranging from 4 to $8 \mathrm{~nm}$ and diameters from 60 to $150 \mathrm{~nm}$ (Figure 1B). The ThT fluorescence signal shown in Figure 1A further verifies the amyloidogenic nature of these round-shape structures. Similar round-shaped amyloid structures were observed with the $\mathrm{A} \beta(1-40)$ peptide (Figure 1A), showing a height of 4-6 and diameter of $60-80 \mathrm{~nm}$ (Figure 1B). Considering the AFM tip convolution effect in the lateral direction, the HEWL and $\mathrm{A} \beta(1-40)$ aggregates can be roughly estimated to be consisted of hundreds to thousands of molecules, respectively, which far exceeds the size of typical oligomers (e.g., 20 or 30 mers). ${ }^{54}$

HEWL and $\mathrm{A} \beta(1-40)$ amyloid aggregates were then deposited on the negatively charged mica surface and developed in a large volume of DI water at room temperature. AFM images show that round-shaped $\mathrm{A} \beta(1-40)$ aggregates associate and form elliptically shaped structures within $4 \mathrm{~h}$ (Figure 1B). The fibrillar structures carrying an intertwisted conformation emerged after $\sim 16 \mathrm{~h}$. In the meantime, quantities of round-shaped aggregates decrease, indicating structural transition (Figure 1B). Staining of ThT reveals the amyloidogenic nature of these developed fibrils (Figures $1 \mathrm{~A}$ and S2). Notably, in the intermediate state (16 h), when aggregates and fibrillar structures coexist, there are fibrils extended in the radial direction away from the core aggregates. These results suggest that fibrillar structures originate from these large amyloidogenic aggregates. In contrast, the fibrillar structures originating from HEWL amyloidogenic aggregates show no hints of an intertwisting morphology (Figure 1C).
The distinction may reflect different packing arrangements of proteinaceous material within the corresponding fibrils.

Compelling evidence suggests that $\mathrm{A} \beta(1-40)$ very rapidly and efficiently forms spherical amyloid aggregates at neutral $\mathrm{pH}$ (Figure S3A-F). In contrast, the conversion from oligomers to amyloid fibrils is slow, following a nucleated conversion mechanism (Figures S3 and S4). ${ }^{5,56}$ The acidic $\mathrm{pH}$ and continuous shaking expedite the process and lead to the formation of mature fibrils (Figure S5) ${ }^{57} \mathrm{~A} \beta(1-40)$ fibrils, which were produced after continuous shaking for 2 weeks, are ca. $1 \mathrm{~nm}$ in height and $30 \mathrm{~nm}$ in width measured by AFM and resemble these surface-directed amyloid structures, indicating a similar packing arrangement. We suspect that the amyloid fibril morphology varies depending on the association mechanism of the round-shaped amyloid aggregates (Figures 1B and S4). As the fibrils on the mica surface were formed by incubation of preformed amyloidogenic aggregates (individual or associated), it is plausible that the fibrillar transition on the mica surface follows a nucleated conformational conversion mechanism similar to the bulk solution.

Conceivably, after being "trapped", the electrostatic interactions between the negatively charged mica surface and positively charged regions of beta-sheet contents help align the otherwise randomly packed amyloidogenic aggregates and thus facilitate the formation of fibrillar structures. ${ }^{58,59}$ Consistently, when the electrostatic interactions are perturbed by the addition of excessive salt, smaller amounts of fibrillar structures emerge on the mica surface (Figure 2A). For example, quantities of fibrillar structures with $50 \mathrm{mM} \mathrm{NaCl}$ diminished down to $\sim 40 \%$ of the ones after 24 h development in DI water. The transition from round-shaped oligomers to intertwisted fibrils is hindered by the increase in ionic strength, and the 

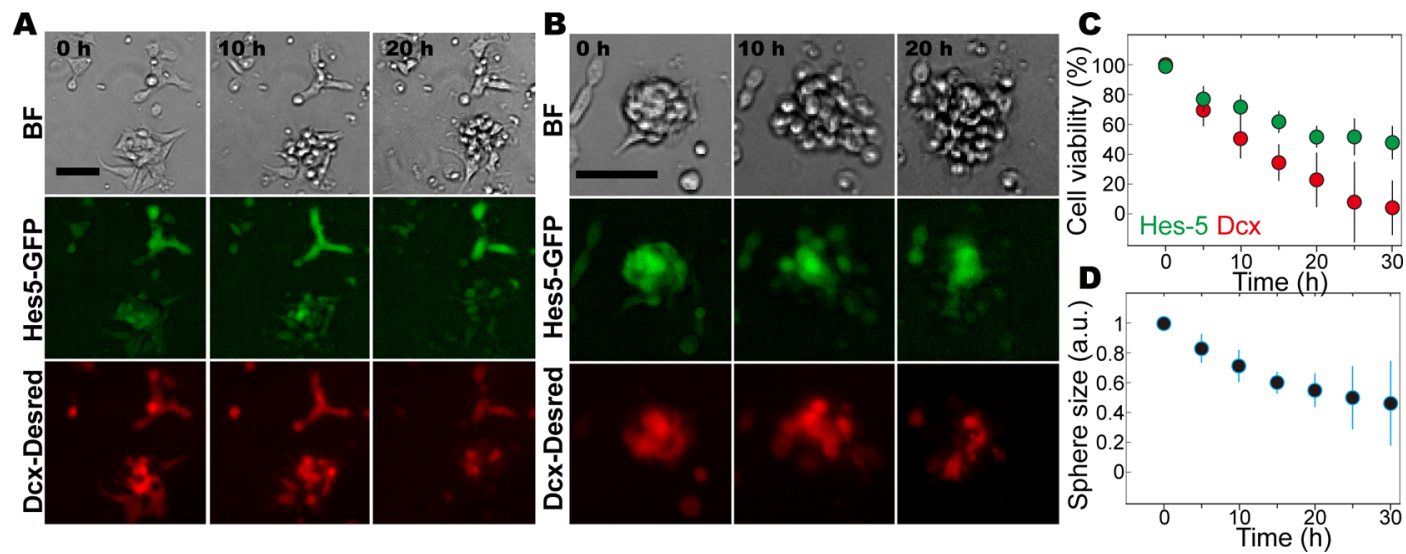

Figure 4. (A,C) Individual NSCs and (B,D) NSC spheres are maintained on the mica surface decorated with A $\beta(1-40)$ amyloid fibrils. For individual NSCs, the number of Dcx-positive cells decreased more significantly compared to Hes5 positive cells, suggesting that NSCs differentiated towards neurons are more sensitive to A $\beta$ amyloid fibrils, while, in the form of NSC spheres, it is observed that within $10 \mathrm{~h}$ incubation on the mica surface decorated with $\mathrm{A} \beta$ amyloid fibrils, NSCs/NGCs detach themselves from the peripherical region of NSC spheres and adopt a round-shaped morphology. Together with images obtained in Hes5-GFP and Dcx-Desred channels, we conclude that detached cells quickly die, and the ones within the sphere remain alive. All these results demonstrate that NSCs with a high Dcx expression level are more vulnerable to A $\beta(1-40)$ amyloids, and NSCs are better protected in spheres. In (C,D), each data point has 5 repeats. Cell viability is assessed by normalizing cell numbers over time to the initial value, and NSC sphere diameter to the original size. Scale bars denote $50 \mu \mathrm{m}$ in all images.

effect depends on the added salt concentration (Figure 2BD). Additionally, with increasing salt concentration, the preformed amyloidogenic aggregates seem to be able to further accumulate, which may be caused by mediated electrostatic interactions.

Effect of Surface-Directed Amyloids on SH-SY5Y and NSCs. The effect of $A \beta(1-40)$ and HEWL amyloids on the viability of SH-SY5Y neuroblastoma cells was assessed by WST-1 assay. SH-SY5Y neuroblastoma cells were preincubated with the amyloid and control samples from 1 to 3 $\mathrm{d}$, followed by measuring the cell viability (Figure 3 ). Freshly dissolved $\mathrm{A} \beta(1-40)$ and its amyloid aggregates formed after $24 \mathrm{~h}$ shaking at neutral $\mathrm{pH}$ did not induce a significant decrease in cell viability. The level of cell survival dropped to ca. $80 \%$ and even to ca. $60 \%$ upon incubation with $\mathrm{A} \beta(1-40)$ fibrils formed after incubation at acidic $\mathrm{pH}$ for 2 and $3 \mathrm{~d}$, respectively (Figure 3A). In contrast, all HEWL samples did not induce observable changes in cell viability under similar experimental conditions (Figure $3 \mathrm{~B}$ ). Considering the fact that $5 \mu \mathrm{L}$ of protein solution was diluted 20 times after mixing with $100 \mu \mathrm{L}$ of cell solution before WST-1 assay, we further increase protein concentration by concentrating HEWL and $\mathrm{A} \beta(1-40)$ amyloid aggregates solutions. A decrease in the cell survival rate down to $50 \%$ for $\mathrm{A} \beta(1-40)$ and $60 \%$ in the presence of HEWL amyloid aggregates was observed when the protein concentration was increased by 5 fold (Figure 3C,D).

The effect of surface-directed $\mathrm{A} \beta(1-40)$ and HEWL amyloid fibrils on the SH-SY5Y cell line was measured by WST-1 upon incubation of cells on the amyloid-coated mica surface (Figure S6). It has been reported that a hydrophilic and negatively charged surface is suitable for cell growth. ${ }^{60}$ Although mica possesses both characters, cell viability on the mica surface decreased by ca. $10 \%$ during $1-2 \mathrm{~d}$ of incubation and by ca. $15 \%$ upon $3 \mathrm{~d}$ of incubation (Figure $3 \mathrm{E}$ ). In the presence of surface-directed $\mathrm{A} \beta(1-40)$ amyloids, the cell survival rate decreased by ca. $20 \%$ on the $2 \mathrm{~d}$ of incubation and by ca. $50 \%$ on $3 \mathrm{~d}$ of incubation, which are statistically significant changes. The viability of cells co-incubated with HEWL fibrils formed on the mica surface did not change on the first day of co-incubation and decreased by ca. $20 \%$ during the second day. There was a significant decrease by ca. $35 \%$ on the third day. These results suggest that the originally nontoxic $\mathrm{A} \beta$ and HEWL aggregates can transit into toxic amyloidogenic structures with the assistance of the negatively charged surface.

The effect of surface-directed amyloids on NSCs was recorded in real-time using fluorescence imaging. When being plated on the mica surface decorated with these amyloid fibrils, NSC death was observed within $20 \mathrm{~h}$ of incubation (Figure 4A,B and Video S1). It is demonstrated that NSCs with a high Dcx level die early (Figure 4C), which is observed as disappeared fluorescence signals (Figure S9), whereas, the number of Hes5-positive NSCs maintains within $20 \mathrm{~h}$ incubation. It is reasonable to conclude that differentiated NSCs (represented by the high Dcx level) are more sensitive to stimulations induced by surface-directed amyloid fibrils. Experiments performed using NSC spheres show similar results. The originally round-shaped and dense morphology of NSC spheres can hardly be maintained when in contact with the mica surface decorated with amyloid fibrils. During the first few hours, NSCs detach themselves from the peripherical region of NSC spheres and adopt a round-shaped morphology. In the meantime, Hes5 fluorescence disappears, suggesting cell death. In bright field images, we observed that organization of NSC spheres is destructed after $20 \mathrm{~h}$. Fluorescence images show that the core of the Hes5-positive cells remains, although with decreased volume (Figure 4D). These results together indicate that NSC death is mostly induced by direct contact with amyloid fibrils, which is consistent with Harte's report that amyloid aggregates are more toxic to differentiated pheochromocytoma (PC12) cells. ${ }^{61}$

Studies on solid model surfaces such as hydrophobic Teflon surfaces, ${ }^{62,63}$ highly ordered pyrolytic graphite surfaces, ${ }^{64}$ hydrophilic silica surfaces, ${ }^{65}$ and hydrophilic mica surfaces ${ }^{64,66}$ can provide mechanistic details on how model surfaces alter and/or promote $\mathrm{A} \beta$ aggregation, elongation and senile plaque formation, which verifies the role of the negatively charged surface in the development of $\mathrm{AD}$ symptoms. ${ }^{67}$ The catalysis 
effect of surfaces (i.e., solid and membrane) is also verified by simulation studies, showing that the membrane can promote the formation of $\beta$-sheets. ${ }^{68-72}$ Indeed, single stranded and rope-like fibrillar structures have been observed on a chemically modified mica surface. ${ }^{73}$ Twisting of protofibrils was rarely observed, possibly due to the electrostatic trapping force provided by the mica surface. In this study, neurotoxic $\mathrm{A} \beta(1-40)$ and HEWL amyloid fibrils are produced by incubating preformed amyloid aggregates on the mica surface in DI water. The difference lies in the fact that we deposit preformed amyloid aggregates on the mica surface instead of a freshly dissolved peptide. In bulk solution and on the surface, fibril growth is accomplished by attaching peptide molecules to the active ends of various fibrillar structures. The proteinaceous material can be protein molecules attached to the mica surface or freely diffused molecules in solution. It is likely that $\mathrm{A} \beta$ monomers and protofibrils bind tightly to the surface, and thus these trapped single-stranded protofibrils cannot twist around one another, as might readily occur in solution. ${ }^{73}$ With preformed amyloid aggregates, amyloid fibrils form by association and rearrangement of the $\beta$-sheet content during incubation in DI water. The volume of the aggregates provides separation from the surface and allows the protofibrils to twist around one another. Moreover, amyloid aggregates are composed of numerous $\beta$-sheet fragments, which are electrostatically polar structures. ${ }^{73}$ The study using all-atom explicit solvent replica exchange molecular dynamics simulations reveals that $\mathrm{A} \beta$ amyloid formation involves the electrostatic interaction among His, Glu and Asp residues. ${ }^{74}$ The negatively charged mica surface may provide alignment and facilitate the association of those amyloid fragments and monomers in the larger amyloid structures. As the twisted conformation is shared by various $\beta$-amyloids and often was toxic, the development of protofilaments from amyloid aggregates on a charged surface may be pathologically related to $\mathrm{AD} .^{75-78}$

The effect of surface-directed amyloids on the neural system is investigated using the neuron-origin SHSY5Y cell-line and NSCs. For SHSY5Y, HEWL and A $\beta(1-40)$ were toxic in two circumstances: developed on the mica surface and large quantities of amyloidogenic aggregates (non-mature fibrils and gels). As mature HEWL and $\mathrm{A} \beta(1-40)$ fibrillar aggregates are not toxic, it is conceivable that surface-directed $A \beta(1-40)$ and HEWL fibrils were the toxic amyloid structures, and the presence of the negatively charged surface in vivo may help convert the non-toxic amyloidogenic aggregates into toxic amyloidogenic structures. Previous studies reveal that formation of amyloidogenic species can directly affect NSCs during the development of neurodegenerative diseases. ${ }^{79}$ Evidence suggests that $\mathrm{A} \beta$ amyloids lead to NSC death and differentiation, ${ }^{80}$ which may exhaust the stem cell pool and hinder the healing process of the neural system. In this study, NSC differentiation and self-maintenance are assessed at the single cell level by tracking Hes5-GFP expression (indicative of self-renewing NSCs) and Dcx-RFP to label neuroblasts (indicating progress towards differentiation). ${ }^{81-86}$ The NSC growth rate is another key feature we quantified to statistically assess the self-renewal of NSCs. By quantitively analyzing realtime NSC imaging on the mica surface decorated with $\mathrm{A} \beta(1-$ 40) amyloids, we demonstrate that NSCs with high expression of Dcx are more vulnerable to toxic $\mathrm{A} \beta$ amyloidogenic structures. However, the effect is diminished when NSCs are maintained as neural spheres, where NSCs are protected from direct contact with $\mathrm{A} \beta$ amyloids. These results suggest that surface-directed amyloids in-vivo may directly cause neuron cell death, but exert less effect on NSCs.

\section{CONCLUSIONS}

Overall, our results, in combination with previous studies, emphasize the importance of physical environmental conditions during $\mathrm{AD}$ development. The negatively charged surface could not only induce the formation of intertwisted protofilaments, but also provide a "dish" filled with $\beta$-sheet structures. These $\beta$-sheet structures may act as "seeds" for further amyloid formation and finally senile plaques.

\section{EXPERIMENTAL SECTION}

Sample Preparation. All chemicals including HEWL were purchased from Sigma-Aldrich, unless mentioned differently. $\mathrm{A} \beta(1-40)$ was produced by Alexotech (Umea, Sweden) in 0.5 $\mathrm{mg}$ weighed aliquots. Experiments were performed by using $\mathrm{A} \beta$ peptide concentrations of $0.1 \mathrm{mg} / \mathrm{mL}$ and HEWL $10 \mathrm{mg} / \mathrm{mL}$, respectively, determined by weight and optical density. HEWL was dissolved in $20 \mathrm{mM}$ glycine buffer, $\mathrm{pH} 2.3$. The $\mathrm{A} \beta(1-40)$ peptide was dissolved at low temperature (on ice) following a protocol released previously. ${ }^{87}$ The chilled $\mathrm{A} \beta$ peptide powder was dissolved in $10 \mathrm{mM} \mathrm{NaOH}$ at a concentration above 1 $\mathrm{mg} / \mathrm{mL}$, followed by sonication in an ice bath for $1 \mathrm{~min}$. Then, a trace amount of $1 \mathrm{M} \mathrm{NaH}_{2} \mathrm{PO}_{4}$ buffer was added to adjust the sample solution to either $\mathrm{pH} 7.4$ or 3.0. The stock solution of the freely diffused $\mathrm{A} \beta$ peptide was diluted to desired concentrations before experiments with neutral $\mathrm{pH}$.

Amyloidogenic structures (i.e., oligomers, large aggregates and mature fibrils) were produced following different operational protocols. To form densely packed amyloid fibrils, the HEWL solution was subjected to shaking at $800 \mathrm{rpm}$ at $57^{\circ} \mathrm{C}$ for a week. An $\mathrm{A} \beta(1-40)$ amyloid gel was formed by incubation at $\mathrm{pH} 3.0$ and $37{ }^{\circ} \mathrm{C}$ for a week with no agitation. Prior to cytotoxicity experiments, $\mathrm{A} \beta(1-40)$ and HEWL amyloid fibrils were dialyzed to $\mathrm{pH} 7.4$ at $4{ }^{\circ} \mathrm{C}$. To produce amyloid aggregates, HEWL $\left(57^{\circ} \mathrm{C}\right.$ and $\left.\mathrm{pH} 2.3\right)$ and $\mathrm{A} \beta(1-$ 40) $\left(37^{\circ} \mathrm{C}\right.$ and $\left.\mathrm{pH} 7.4\right)$ were subjected to agitation at $800 \mathrm{rpm}$ for $24 \mathrm{~h}$. The surface directed protofilaments formed by deposition of amyloid aggregates on a mica surface. Firstly, $\mathrm{A} \beta(1-40)$ and HEWL amyloid aggregate solutions were kept on the mica surface for 30 and $5 \mathrm{~min}$, respectively. Different deposition times were needed due to the difference in concentrations. Mica pieces of $\sim 1 \mathrm{~cm}$ by $1 \mathrm{~cm}$ in size carrying amyloid aggregates were then thoroughly washed in running water and incubated in a Petri dish holding a large volume of DI water $(\sim 10 \mathrm{~mL})$ at room temperature for $24 \mathrm{~h}$ before AFM, FM imaging, and cell viability tests.

ThT Assay. A ThT stock solution was prepared by dissolving $2.5 \mathrm{mM}$ ThT (Merck Schuchardt) in phosphate buffer (10 mM phosphate, $150 \mathrm{mM} \mathrm{NaCl}, \mathrm{pH} 7.4)$ and filtered before use. This stock solution was diluted 50 -fold in the phosphate buffer to produce a working solution. $10 \mu \mathrm{L}$ of protein aliquots were collected and added to $300 \mu \mathrm{L}$ of the working solution. The mixture was incubated in the dark for 1 min to allow ThT binding. The ThT fluorescence intensity was measured using a FluoroMax-2 spectrofluorometer (JobinYvon/Psex Instruments). The excitation and emission wavelengths are 440 and $485 \mathrm{~nm}$, respectively. The slit width is 5 $\mathrm{nm}$. The ThT fluorescence intensities were normalized to the fluorescence intensity of the free dye in solution. 
Atomic Force Microscopy. All imaging experiments were carried out at room temperature in air with a Dimension 3000, Veeco, Woodbury, NY, and a PicoPlus, Agilent atomic force microscope. Images were acquired in the tapping mode with silicon $(\mathrm{Si})$ cantilevers (spring constant of $20-100 \mathrm{~N} / \mathrm{m}$ ) and operated below their resonance frequency (typically 230-410 $\mathrm{kHz}$ ). The images were flattened. The contrast and brightness were adjusted for optimum viewing conditions. Amyloid samples produced in solution were deposited on the surface of freshly cleaved mica (Good Fellow) for 5 min (HEWL) and $30 \mathrm{~min}(\mathrm{~A} \beta(1-40))$. The mica pieces were washed 3 times with $200 \mu \mathrm{L}$ of DI water and dried in a flow of $\mathrm{N}_{2}$ gas at room temperature. The samples with surface-directed fibrils were taken out from DI water and dried with a flow $\mathrm{N}_{2}$ gas prior to imaging.

Fluorescence Imaging. $\mathrm{A} \beta(1-40)$ and HEWL amyloid structures were deposited on mica. To visualize the structures, mica pieces were flushed with a $100 \mu \mathrm{M}$ ThT solution, followed by washing with DI water3-5 times. The fluorescence of the stained amyloids was visualized with an Olympus IX71 inverted fluorescence microscope equipped with a $100 \mathrm{~W}$ mercury lamp, a UV filter set, and a $60 \times$ oil immersion objective. A UV light shutter controlled the exposure time of ThT fluorescence. Images were recorded using a charge coupled device camera (Olympus DP 70).

Cell Culture. SH-SY5Y neuroblastoma cells (ATCC CRL2266) were routinely cultured in the Dulbecco's modified Eagle medium (DMEM) supplemented with $10 \%$ (v/v) fetal bovine serum. NSCs were isolated and cultured from rat embryos of day 16.5. Disassociated cortical hemispheres were cut into $1 \mathrm{~mm} 3$ pieces in ice-cold phosphate-buffered saline (PBS, pH 7.2) with $10 \mathrm{mM}$ D-glucose. Small pieces of cortical tissue were collected and enzymatically dissociated by using a Papain Dissociation System as indicative materials (Worthington Biochemical Corp). Neurospheres composed of NSCs formed in 1 week of initial planting in the Neurobasal medium (Invitrogen) containing 2\% (v/v) NS21 supplement, $0.5 \mathrm{mM}$ L-glutamine, 100 units $/ \mathrm{mL}$ penicillin and $100 \mathrm{mg} / \mathrm{mL}$ streptomycin in an incubator with $95 \%$ humidity, $37{ }^{\circ} \mathrm{C}$ and $5 \%(\mathrm{v} / \mathrm{v}) \mathrm{CO}_{2}$. The NSCs were passaged weekly by mechanically and enzymatically dissociating the neurospheres. Both SH-SY5Y and NSC viable cells were counted following staining with $0.2 \%(\mathrm{w} / \mathrm{v})$ trypan blue (Gibco/Invitrogen) and plated at a density of 10,000 cells per well $(100,000$ cells $/ \mathrm{mL})$ in a 96-well black-walled imaging plate (BD Falcon). To investigate the effect of surface-directed amyloids on NSCs, specially cut mica pieces with and without preattached amyloid structures were positioned on the bottom of the well, followed by the same procedure of cell culturing (Figure S5).

WST-1 Cell Viability Assay. In viable cells, WST-1 undergoes reduction by mitochondrial dehydrogenases (succinatetetrazoliumreductase system) to soluble formazan, which serves as an indicator of the quantity of metabolically active cells. $10 \mu \mathrm{L}$ of WST-1 reagent was added and coincubated with the cell solutions at $37^{\circ} \mathrm{C}$ for $4 \mathrm{~h}$ to evaluate cell viability. The absorbance was measured using an ELISA plate reader (LabSystems Multiskan RC) at $450 \mathrm{~nm}$. The cell viability was expressed as a percentage of absorbance in wells containing cells treated with amyloids compared to the control cells.

Live-Cell Fluorescence Microscopy. For image acquisition, a Nikon Ti2E microscope with an automated translational stage and a digital CMOS camera (ORCA-Flash 4.0,
Hamamatsu, Japan) was used. The stage and image acquisition was controlled via NIS Elements software (Nikon, Japan). During imaging, the external conditions were set to standard culture conditions $\left(5 \% \mathrm{CO}_{2}\right.$ and $37{ }^{\circ} \mathrm{C}$ external temperature) and maintained at this level.

\section{ASSOCIATED CONTENT}

\section{Supporting Information}

The Supporting Information is available free of charge at https://pubs.acs.org/doi/10.1021/acsomega.9b03671.

Assessment of $\mathrm{A} \beta(1-40)$ and HEWL amyloid formation with and without continuous shaking using ThT binding assay (Figure S1); fluorescence images showing mica surface-directed $\mathrm{A} \beta(1-40)$ amyloid formation (Figure S2); atomic force microscopy (AFM) height images showing the $\mathrm{A} \beta(1-40)$ amyloid formation process without shaking (Figure S3); schematic drawing shows the possible underlying mechanism of surface-directed A $\beta$ amyloid fibril formation (Figure S4); AFM images of HEWL and $\mathrm{A} \beta(1-40)$ in a gel-form after shaking for 2 weeks (Figure S5); experimental procedure of cell culturing on the mica surface (Figure S6) (PDF)

Comparison between NSCs deposited on the mica surface coated with freshly dissolved $\mathrm{A} \beta(1-40)$ and the mica surface with preformed $\mathrm{A} \beta(1-40)$ amyloids (Video S1) (AVI)

\section{AUTHOR INFORMATION}

\section{Corresponding Authors}

Yonggang Liu - Laboratory of Stem Cell and Tissue Engineering, Chongqing Medical University, Chongqing 400016, China; Email: 100418@cqmu.edu.cn

Ludmilla A. Morozova-Roche - Department of Medical Biochemistry and Biophysics, Umeå University, Umeå 90187, Sweden; (1) orcid.org/0000-0001-5886-2023;

Email: ludmilla.morozova-roche@umu.se

Ce Zhang - State Key Laboratory of Cultivation Base for Photoelectric Technology and Functional Materials, Institute of Photonics and Photon-Technology, Northwest University, Xi'an 710069, China; ○ orcid.org/0000-0003-1284-7279; Email: zhangce.univ@gmail.com

\section{Authors}

Hao Chen - School of Chemical Engineering, Northwest University, Xi'an 710069, China

Dan Sun - State Key Laboratory of Cultivation Base for Photoelectric Technology and Functional Materials, Institute of Photonics and Photon-Technology, Northwest University, Xi'an 710069, China

Yin Tian - Laboratory of Stem Cell and Tissue Engineering, Chongqing Medical University, Chongqing 400016, China

Haiming Fan - College of Chemistry and Materials Science, Northwest University, Xi'an 710127, China; (1) orcid.org/ 0000-0002-0091-772X

Complete contact information is available at:

https://pubs.acs.org/10.1021/acsomega.9b03671

\section{Author Contributions}

${ }^{\#}$ H.C. and D.S. contributed equally to this work.

\section{Author Contributions}

H.C. and D.S. made equal contributions. H.F., H.C., and Y.T. performed the experiments. Y.T. performed calculations and 
data analysis. Y.L., C.Z., and L.A.M.-R. designed the project. Y.L., C.Z., and L.A.M.-R. prepared the manuscript.

\section{Notes}

The authors declare no competing financial interest.

\section{ACKNOWLEDGMENTS}

This work was supported by the Chongqing Basic and Frontier Research Program Project (cstc2015jcyjA10034), Swedish Medical Research Council (2014-3241 to L.A.M.-R.), Insamlingsstiftelsen (FS 2.1.12-1605-14 to L.A.M.-R.), Biochemical Imaging Platform, and Umeå University (to L.A.M.-R.).

\section{REFERENCES}

(1) Abelein, A.; Abrahams, J. P.; Danielsson, J.; Gräslund, A.; Jarvet, J.; Luo, J.; Tiiman, A.; Wärmländer, S. K. T. S. The hairpin conformation of the amyloid $\beta$ peptide is an important structural motif along the aggregation pathway. J. Biol. Inorg. Chem. 2014, 19, 623-634.

(2) Goedert, M. Alpha-synuclein and neurodegenerative diseases. Nat. Rev. 2001, 2, 492-501.

(3) Maries, E.; Dass, B.; Collier, T. J.; Kordower, J. H.; SteeceCollier, K. The role of alpha-synuclein in Parkinson's disease: insights from animal models. Nat. Rev. Neurosci. 2003, 4, 727-738.

(4) Irwin, D. J.; Lee, V. M.-Y.; Trojanowski, J. Q. Parkinson's disease dementia: convergence of $\alpha$-synuclein, tau and amyloid- $\beta$ pathologies. Nat. Rev. Neurosci. 2013, 14, 626-636.

(5) Lee, H.-J.; Bae, E.-J.; Lee, S.-J. Extracellular $\alpha$-synuclein-a novel and crucial factor in Lewy body diseases. Nat. Rev. Neurol. 2014, 10, 92-98.

(6) Cattaneo, E.; Zuccato, C.; Tartari, M. Normal huntingtin function: An alternative approach to Huntington's disease. Nat. Rev. Neurosci. 2005, 6, 919-930.

(7) Weissmann, C. The state of the prion. Nat. Rev. Microbiol. 2004, 2, 861-871.

(8) Aguzzi, A.; Heikenwalder, M.; Polymenidou, M. Insights into prion strains and neurotoxicity. Nat. Rev. Mol. Cell Biol. 2007, 8, 552561.

(9) Mead, S.; Reilly, M. M. A new prion disease: relationship with central and peripheral amyloidoses. Nat. Rev. Neurol. 2015, 11, 9097.

(10) Prusiner, S. B. Prions Nobel Lecture: Prions. Proc. Natl. Acad. Sci. U.S.A. 1998, 95, 13363-13383.

(11) Kahn, S. E. The relative contributions of insulin resistance and beta-cell dysfunction to the pathophysiology of Type 2 diabetes. Diabetologia 2003, 46, 3-19.

(12) Höppener, J. W. M.; Ahrén, B.; Lips, C. J. M. Islet amyloid and type 2 diabetes mellitus. N. Engl. J. Med. 2000, 343, 411-419.

(13) Cooper, G. J.; Willis, A. C.; Clark, A.; Turner, R. C.; Sim, R. B.; Reid, K. B. Purification and characterization of a peptide from amyloid-rich pancreases of type 2 diabetic patients. Proc. Natl. Acad. Sci. U.S.A. 1987, 84, 8628-8632.

(14) Butler, A. E.; Janson, J.; Bonner-Weir, S.; Ritzel, R.; Rizza, R. A.; Butler, P. C. $\beta$-cell deficit and increased $\beta$-cell apoptosis in humans with type 2 diabetes. Diabetes 2003, 52, 102-110.

(15) Clark, A.; Lewis, C. E.; Willis, A. C.; Cooper, G. J. S.; Morris, J. F.; Reid, K. B. M.; Turner, R. C. Islet amyliod formed from diabetesassociated peptide may be pathogenic in type-2 diabetes. Lancet 1987, 330, 231-234.

(16) Jaikaran, E. T. A. S.; Clark, A. Islet amyloid and type 2 diabetes: from molecular misfolding to islet pathophysiology. Biochim. Biophys. Acta, Mol. Basis Dis. 2001, 1537, 179-203.

(17) Wang, C.; Yang, A.; Li, X.; Li, D.; Zhang, M.; Du, H.; Li, C.; Guo, Y.; Mao, X.; Dong, M.; Besenbacher, F.; Yang, Y.; Wang, C. Observation of molecular inhibition and binding structures of amyloid peptides. Nanoscale 2012, 4, 1895-1909.
(18) Zhu, M.; Li, J.; Fink, A. L. The association of $\alpha$-synuclein with membranes affects bilayer structure, stability, and fibril formation. $J$. Biol. Chem. 2003, 278, 40186-40197.

(19) Dikiy, I.; Eliezer, D. Folding and misfolding of alpha-synuclein on membranes. Biochim. Biophys. Acta, Biomembr. 2012, 1818, 10131018.

(20) Chiti, F.; Dobson, C. M. Protein misfolding, functional amyloid, and human disease. Annu. Rev. Biochem. 2006, 75, 333-366.

(21) Ross, C. A.; Poirier, M. A. Protein aggregation and neurodegenerative disease. Nat. Med. 2004, 10, S10-S17.

(22) Deshpande, A.; Mina, E.; Glabe, C.; Busciglio, J. Different conformations of amyloid $\beta$ induce neurotoxicity by distinct mechanisms in human cortical neurons. J. Neurosci. 2006, 26, 6011-6018.

(23) Acosta, D. M. Á. V.; Vega, B. C.; Basurto, J. C.; Morales, L. G. F.; Rosales Hernández, M. C. Recent Advances by In Silico and In Vitro Studies of Amyloid- $\beta(1-42)$ Fibril Depicted a S-Shape Conformation. Int. J. Mol. Sci. 2018, 19, 2415.

(24) Brännström, K.; Islam, T.; Sandblad, L.; Olofsson, A. The role of histidines in amyloid $\beta$ fibril assembly. FEBS Lett. 2017, 591, $1167-1175$

(25) Lin, Y.-C.; Repollet-Pedrosa, M. H.; Ferrie, J. J.; Petersson, E. J.; Fakhraai, Z. Potential artifacts in sample preparation methods used for imaging amyloid oligomers and protofibrils due to surfacemediated fibril formation. J. Phys. Chem. B 2017, 121, 2534-2542.

(26) Mizuguchi, C.; Nakamura, M.; Kurimitsu, N.; Ohgita, T.; Nishitsuji, K.; Baba, T.; Shigenaga, A.; Shimanouchi, T.; Okuhira, K.; Otaka, A.; Saito, H. Effect of phosphatidylserine and cholesterol on membrane-mediated fibril formation by the $\mathrm{N}$-terminal amyloidogenic fragment of apolipoprotein AI. Sci. Rep. 2018, 8, 5497.

(27) Buell, A. K.; Galvagnion, C.; Gaspar, R.; Sparr, E.; Vendruscolo, M.; Knowles, T. P. J.; Linse, S.; Dobson, C. M. Solution conditions determine the relative importance of nucleation and growth processes in $\alpha$-synuclein aggregation. Proc. Natl. Acad. Sci. U.S.A. 2014, 111, $7671-7676$.

(28) Monti, D. M.; Guglielmi, F.; Monti, M.; Cozzolino, F.; Torrassa, S.; Relini, A.; Pucci, P.; Arciello, A.; Piccoli, R. Effects of a lipid environment on the fibrillogenic pathway of the $\mathrm{N}$-terminal polypeptide of human apolipoprotein AI, responsible for in vivo amyloid fibril formation. Eur. Biophys. J. 2010, 39, 1289-1299.

(29) Zhao, H.; Tuominen, E. K. J.; Kinnunen, P. K. J. Formation of amyloid fibers triggered by phosphatidylserine containing membranes. Biochemistry 2004, 43, 10302-10307.

(30) Knight, J. D.; Miranker, A. D. Phospholipid catalysis of diabetic amyloid assembly. J. Mol. Biol. 2004, 341, 1175-1187.

(31) Galvagnion, C.; Buell, A. K.; Meisl, G.; Michaels, T. C. T.; Vendruscolo, M.; Knowles, T. P. J.; Dobson, C. M. Lipid vesicles trigger $\alpha$-synuclein aggregation by stimulating primary nucleation. Nat. Chem. Biol. 2015, 11, 229-234.

(32) Zhang, X.; Clair, J. R.; London, E.; Raleigh, D. P. Islet amyloid polypeptide membrane interactions: effects of membrane composition. Biochemistry 2017, 56, 376-390.

(33) Shimada, K.; Maeda, S.; Murakami, T.; Nishiguchi, S.; Tashiro, F.; Yi, S.; Wakasugi, S.; Takahashi, K.; Yamamura, K. Transgenic mouse model of familial amyloidotic polyneuropathy. Mol. Biol. Med. 1989, 6, 333-343.

(34) Yankner, Y.; Duffy, D.; Kirschner, K. Neurotrophic and neurotoxic effects of amyloid beta protein: reversal by tachykinin neuropeptides. Science 1990, 250, 279-282.

(35) Iversen, L. L.; Mortishire-Smith, R. J.; Pollack, S. J.; Shearman, M. S. The toxicity in vitro of $\beta$-amyloid protein. Biochem. J. 1995, 311, $1-16$.

(36) Campioni, S.; Mannini, B.; Zampagni, M.; Pensalfini, A.; Parrini, C.; Evangelisti, E.; Relini, A.; Stefani, M.; Dobson, C. M.; Cecchi, C.; Chiti, F. A causative link between the structure of aberrant protein oligomers and their toxicity. Nat. Chem. Biol. 2010, 6, 140147.

(37) Sipe, J. D.; Cohen, A. S. History of the amyloid fibril. J. Struct. Biol. 2000, 130, 88-98. 
(38) Maji, S. K.; Wang, L.; Greenwald, J.; Riek, R. Structure activity relationship of amyloid fibrilsStructure-activity relationship of amyloid fibrils. FEBS Lett. 2009, 583, 2610-2617.

(39) Eisenberg, D.; Jucker, M. The amyloid state of proteins in human diseases. Cell 2012, 148, 1188-1203.

(40) Walsh, D. M.; Selkoe, D. J. A $\beta$ oligomers a decade of discovery. J. Neurochem. 2007, 101, 1172-1184.

(41) Kim, H.-J.; Chae, S.-C.; Lee, D.-K.; Chromy, B.; Lee, S. C.; Park, Y.-C.; Klein, W. L.; Krafft, G. A.; Hong, S.-T. Selective neuronal degeneration induced by soluble oligomeric amyloid beta protein. FASEB J. 2003, 17, 118-120.

(42) Reixach, N.; Deechongkit, S.; Jiang, X.; Kelly, J. W.; Buxbaum, $\mathrm{J}$. N. Tissue damage in the amyloidoses: Transthyretin monomers and nonnative oligomers are the major cytotoxic species in tissue culture. Proc. Natl. Acad. Sci. U.S.A. 2004, 101, 2817-2822.

(43) Oddo, S.; Caccamo, A.; Tran, L.; Lambert, M. P.; Glabe, C. G.; Klein, W. L.; LaFerla, F. M. Temporal profile of amyloid- $\beta$ (A $\beta$ ) oligomerization in an in vivo model of Alzheimer disease A link between A $\beta$ and tau pathology. J. Biol. Chem. 2006, 281, 1599-1604.

(44) Vieira, M. N. N.; Forny-Germano, L.; Saraiva, L. M.; Sebollela, A.; Martinez, A. M. B.; Houzel, J.-C.; De Felice, F. G.; Ferreira, S. T. Soluble oligomers from a non-disease related protein mimic $\mathrm{A} \beta$ induced tau hyper-phosphorylation and neurode-generation. J. Neurochem. 2007, 103, 736-748.

(45) Zhang, C.; Yonggang, L.; Jonathan, G.; van der Maarel Johan, R. C. MRP14 (S100A9) Protein Interacts with Alzheimer BetaAmyloid Peptide and Induces Its Fibrillization. PloS One 2012, 7, No. e32953.

(46) Qin, H.; Dan, S.; Zubair, H. M.; Yonggang, L.; MorozovaRoche, L. A.; Zhang, C. HEWL interacts with dissipated oleic acid micelles, and decreases oleic acid cytotoxicity. PloS One 2019, 14, No. e0212648.

(47) Drolle, E.; Negoda, A.; Hammond, K.; Pavlov, E.; Leonenko, Z. Changes in lipid membranes may trigger amyloid toxicity in Alzheimer's disease. PloS One 2017, 12, No. e0182194.

(48) Viennet, T.; Wördehoff, M. M.; Uluca, B.; Poojari, C.; Shaykhalishahi, H.; Willbold, D.; Strodel, B.; Heise, H.; Buell, A. K.; Hoyer, W.; Etzkorn, M. Structural insights from lipid-bilayer nanodiscs link $\alpha$-Synuclein membrane-binding modes to amyloid fibril formation. Commun. Biol. 2018, 1, 44.

(49) Shezad, K.; Zhang, K.; Hussain, M.; Dong, H.; He, C.; Gong, X.; Xie, X.; Zhu, J.; Shen, L. Surface roughness modulates diffusion and fibrillation of amyloid- $\beta$ peptide. Langmuir 2016, 32, 8238-8244. (50) Bucciantini, M.; Giannoni, E.; Chiti, F.; Baroni, F.; Formigli, L.; Zurdo, J.; Taddei, N.; Ramponi, G.; Dobson, C. M.; Stefani, M. Inherent toxicity of aggregates implies a common mechanism for protein misfolding diseases. Nature 2002, 416, 507-511.

(51) Chipman, D. M.; Sharon, N. Mechanism of Lysozyme Action. Science 1969, 165, 454-465.

(52) Gouras, G. K.; Olsson, T. T.; Hansson, H. $\beta$-amyloid Peptides and Amyloid Plaques in Alzheimer's Disease. Neurotherapeutics 2015, $12,3-11$.

(53) Chen, G.-f.; Tinghai, X.; Yan, Y.; Yuren, Z.; Yi, J.; Karsten, M.; Eric, X. H. Amyloid beta: structure, biology and structure-based therapeutic development. Acta Pharmacol. Sin. 2017, 38, 1205-1235.

(54) Malisauskas, M.; Ostman, J.; Darinskas, A.; Zamotin, V.; Liutkevicius, E.; Lundgren, E.; Morozova-Roche, L. A. Does the cytotoxic effect of transient amyloid oligomers from common equine lysozyme in vitro imply innate amyloid toxicity? J. Biol. Chem. 2005, 280, 6269-6275.

(55) Lee, J.; Culyba, E. K.; Powers, E. T.; Kelly, J. W. Amyloid- $\beta$ forms fibrils by nucleated conformational conversion of oligomers. Nat. Chem. Biol. 2011, 7, 602-609.

(56) Sarroukh, R.; Cerf, E.; Derclaye, S.; Dufrêne, Y. F.; Goormaghtigh, E.; Ruysschaert, J.-M.; Raussens, V. Transformation of amyloid $\beta(1-40)$ oligomers into fibrils is characterized by a major change in secondary structure. Cell. Mol. Life Sci. 2011, 68, 14291438.
(57) Trumbore, C. N. Shear-Induced Amyloid Formation in the Brain: I. Potential Vascular and Parenchymal Processes. J. Alzheimer's Dis. 2016, 54, 457-470.

(58) Zhao, L. N.; Tong, Z.; Ce, Z.; Chao, W.; Morozova-Roche, L. A.; Yue, C. L.; Yuguang, M. S100A9 induces aggregation-prone conformation in $\mathrm{A} \beta$ peptides: a combined experimental and simulation study. RSC Adv. 2013, 3, 24081-24089.

(59) Weixin, X.; Ce, Z.; Ludmilla, M. R.; Zhang, J. Z. H.; Yuguang, M. pH-Dependent Conformational Ensemble and Polymorphism of Amyloid- $\beta$ Core Fragment. J. Phys. Chem. B 2013, 117, 8392-8399.

(60) Fawzi, N. L.; Ying, J.; Ghirlando, R.; Torchia, D. A.; Clore, G. M. Atomic-resolution dynamics on the surface of amyloid- $\beta$ protofibrils probed by solution NMR. Nature 2011, 480, 268-272.

(61) Harte, N. P.; Klyubin, I.; McCarthy, E. K.; Min, S.; Garrahy, S. A.; Xie, Y.; Davey, G. P.; Boland, J. J.; Rowan, M. J.; Mok, K. H. Amyloid Oligomers and Mature Fibrils Prepared from an Innocuous Protein Cause Diverging Cellular Death Mechanisms. J. Biol. Chem. 2015, 290, 28343-28352.

(62) Giacomelli, C. E.; Norde, W. Influence of hydrophobic Teflon particles on the structure of amyloid $\beta$-peptide. Biomacromolecules 2003, 4, 1719-1726.

(63) Linse, S.; Cabaleiro-Lago, C.; Xue, W.-F.; Lynch, I.; Lindman, S.; Thulin, E.; Radford, S. E.; Dawson, K. A. Nucleation of protein fibrillation by nanoparticles. Proc. Natl. Acad. Sci. U.S.A. 2007, 104, 8691-8696.

(64) Kowalewski, T.; Holtzman, D. M. In situ atomic force microscopy study of Alzheimer's $\beta$-amyloid peptide on different substrates: New insights into mechanism of $\beta$-sheet formation. Proc. Natl. Acad. Sci. U.S.A. 1999, 96, 3688-3693.

(65) Giacomelli, C. E.; Norde, W. Conformational Changes of the Amyloid $\beta$-Peptide (1-40) Adsorbed on Solid Surfaces. Macromol. Biosci. 2005, 5, 401-407.

(66) Blackley, H. K. L.; Sanders, G. H. W.; Davies, M. C.; Roberts, C. J.; Tendler, S. J. B.; Wilkinson, M. J. In-situ atomic force microscopy study of $\beta$-amyloid fibrillization. J. Mol. Biol. 2000, 298, $833-840$.

(67) Barrow, C.; Zagorski, M. Solution structures of $\beta$ peptide and its constituent fragments: relation to amyloid deposition. Science 1991, 253, 179-182.

(68) Tang, J.; Alsop, R. J.; Backholm, M.; Dies, H.; Shi, A.-C.; Rheinstädter, M. C. Amyloid- $\beta 25-35$ peptides aggregate into cross- $\beta$ sheets in unsaturated anionic lipid membranes at high peptide concentrations. Soft Matter 2016, 12, 3165-3176.

(69) Nikolic, A.; Baud, S.; Rauscher, S.; Pomès, R. Molecular mechanism of $\beta$-sheet self-organization at water-hydrophobic interfaces. Proteins: Struct., Funct., Bioinf. 2011, 79, 1-22.

(70) Zhao, L. N.; Chiu, S.-W.; Benoit, J.; Chew, L. Y.; Mu, Y. Amyloid $\beta$ peptides aggregation in a mixed membrane bilayer: A molecular dynamics study. J. Phys. Chem. B 2011, 115, 12247-12256.

(71) Brown, A. M.; Bevan, D. R. Molecular Dynamics Simulations of Amyloid $\beta$-Peptide (1-42): Tetramer Formation and Membrane Interactions. Biophys. J. 2016, 111, 937-949.

(72) Lemkul, J. A.; Bevan, D. R. Aggregation of Alzheimer's amyloid $\beta$-peptide in biological membranes: A molecular dynamics study. Biochemistry 2013, 52, 4971-4980.

(73) Moores, B.; Drolle, E.; Attwood, S. J.; Simons, J.; Leonenko, Z. Effect of surfaces on amyloid fibril formation. PLoS One 2011, 6, No. e25954.

(74) Xu, W.; Zhang, C.; Derreumaux, P.; Gräslund, A.; MorozovaRoche, L.; $\mathrm{Mu}, \mathrm{Y}$. Intrinsic determinants of $\mathrm{A} \beta(12-24) \mathrm{pH}-$ dependent self-assembly revealed by combined computational and experimental studies. PLoS One 2011, 6, No. e24329.

(75) Lue, L.-F.; Kuo, Y.-M.; Roher, A. E.; Brachova, L.; Shen, Y.; Sue, L.; Beach, T.; Kurth, J. H.; Rydel, R. E.; Rogers, J. Soluble amyloid $\beta$ peptide concentration as a predictor of synaptic change in Alzheimer's disease. Am. J. Pathol. 1999, 155, 853-862.

(76) Rowan, M. J.; Klyubin, I.; Wang, Q.; Hu, N. W.; Anwyl, R. Synaptic memory mechanisms: Alzheimer's disease amyloid beta- 
peptide induced dysfunction. Biochem. Soc. Trans. 2007, 35, 12191223.

(77) McLean, C. A.; Cherny, R. A.; Fraser, F. W.; Fuller, S. J.; Smith, M. J.; Konrad Vbeyreuther, K.; Bush, A. I.; Masters, C. L. Soluble pool of $\mathrm{A} \beta$ amyloid as a determinant of severity of neurodegeneration in Alzheimer's disease. Ann. Neurol. 1999, 46, 860-866.

(78) Bokvist, M.; Lindström, F.; Watts, A.; Gröbner, G. Two types of Alzheimer's $\beta$-amyloid (1-40) peptide membrane interactions: aggregation preventing transmembrane anchoring versus accelerated surface fibril formation. J. Mol. Biol. 2004, 335, 1039-1049.

(79) Bernabeu-Zornoza, A.; Coronel, R.; Lachgar, M.; Palmer, C.; Liste, I. Effects of Amyloid- $\beta$ Peptide on the Biology of Human Neural Stem Cells. Methods Mol. Biol. 2018, 1779, 381-398.

(80) Lee, I.-S.; Jung, K.; Kim, I.-S.; Park, K. I. Amyloid- $\beta$ oligomers regulate the properties of human neural stem cells through GSK-3 $\beta$ signaling. Exp. Mol. Med. 2013, 45, No. e60.

(81) Basak, O.; Taylor, V. Identification of self-replicating multipotent progenitors in the embryonic nervous system by high Notch activity and Hes5 expression. Eur. J. Neurosci. 2007, 25, 10061022.

(82) Basak, O.; Giachino, C.; Fiorini, E.; MacDonald, H. R.; Taylor, V. Neurogenic subventricular zone stem/progenitor cells are Notch1dependent in their active but not quiescent state. J. Neurosci. 2012, 32, $5654-5666$.

(83) Lugert, S.; Basak, O.; Knuckles, P.; Haussler, U.; Fabel, K.; Götz, M.; Haas, C. A.; Taylor, G.; Giachino, C. Quiescen and active hippocampal neural stem cells with distinct morphologies respond selectively to physiological and pathological stimuli and aging. Cell Stem Cell 2010, 6, 445-456.

(84) Sykova, E.; Forostyak, S. Stem cells in regenerative medicine. Laser Ther. 2013, 22, 87-92.

(85) Behnan, J.; Grieg, Z.; Joel, M.; Ramsness, I.; Stangeland, B. Gene knockdown of CENPA reduces sphere forming ability and stemness of glioblastoma initiating cells. Neuroepigenetics 2016, 7, 618.

(86) Couillard-Despres, S.; Winner, B.; Karl, C.; Lindemann, G.; Schmid, P.; Aigner, R.; Aigner, L. Targeted transgene expression in neuronal precursors: watching young neurons in the old brain. Eur. J. Neurosci. 2006, 24, 1535-1545.

(87) Müller, R.; Laschober, C.; Szymanski, W. W.; Allmaier, G. Determination of molecular weight, particle size, and density of high number generation PAMAM dendrimers using MALDI-TOF-MS and nES-GEMMA. Macromolecules 2007, 40, 5599-5605. 